Ellegren, H. (1992): Polymerase-chain reaction (PCR) analysis of microsatelliets-a new approach to studies of genetic relationships in birds. Auk 109: 886-895.

Excoffier, L., P. E. Smouse and J. M. QuATtro (1992): Analysis of molecular variance inferred from metric distances among DNA haplotypes: application to human mitochondrial DNA restriction data. Genetics 131: 479-491.

GreEnwood, M. S. (1986): Gene exchange in loblolly pine: the relation between pollination mechanism, female receptivity and pollen availability. Am J Bot 73: 1443-1451.

Hardy, O. J., S. C. Gonzales-Martinez, B. Colas, H. Frville, A. Mignot and I. Olivieri (2004): Fine-scale genetic structure and gene dispersal in Centaurea corymbosa (Asteraceae). II. Correlated paternity within and among shibships. Genetics 168: 1601-1614.

Isagi, Y., T. Kanazashi, W. Suzuki, H. Tanaka and T. AbE 2000): Microsatellite analysis of the regeneration process of Magnolia obovata Thunb. Heredity 84: 143-151.

ISAGI, Y. and S. SUHANDONO (1997): PCR primers amplifying microsatellite loci of Quercus mysinifolia Blume and their conservation between oak species. Mol Ecol 6: 897-899.

IтоW, S. (1991): Species turnover and diversity patterns along an evergreen broad-leaved forest cenocline. J Veg Sci 2: 477-484.

KAmpfer, S., C. Lexer, J. Glossl and H. Steinkellner (1998): Characterization of (GA) microsatellite loci from Quercus robur. Hereditas 129: $183-186$.

KIRA, T. (1991): Forest ecosystem of east and southeast Asia in a global perspective. Ecol Res 6: 185-200.

Levin, D. A. and H. W. Kerster (1969): The dependence of beemediated pollen and gene dispersal upon plant density. Evolution 23: $560-571$.

Linhart, Y. B., W. H. Busby, J. H. Beach and P. Feinsinger (1987): Forager behavior, pollen dispersal and inbreeding in two species of hummingbird-pollinated plants. Evolution 41 : 679-682.

Manabe, T., N. Nishimura, M. Miura and S. Yamamoto (2000): Population structure and spatial patterns for trees in a temperate old-growth evergreen broad-leaved forest in Japan. Plant Ecol 151: 181-197.
MANTEL, N. (1967): The detection of disease clustering and a generalized regression approach. Cancer Res 27: 209-220.

Marshall, T. C., J. Slate, L. E. B. KruUk and J. M. Pemberton (1998): Statistical confidence for likelihood-based paternity inference in natural populations. Mol Ecol 7: 639-655.

Mosquin, T. (1971): Competition for pollinators as a stimulus for the evolution of flowering time. Oikos 22: 398-402.

MURRAY, M. G. and W. F. THOMPSON (1980): Rapid isolation of high molecular weight plant DNA. Nucleic Acids Res 8: $4321-4325$.

NixON, K. C. (1993): Infrageneric classification of Quercus (Fagaceae) and typification of sectional names. Annales des sciences forestieres (Suppl) 50: 25-34.

Queller, D. C. and K. F. Goodnight (1989): Estimating relatedness using genetic markers. Evolution 43: 258-275.

RAYMOND, M. and F. Rousset (1995): GENEPOP (version 1.2): population genetics software for exact tests and ecumenicism. Journal of Heredity 86: 248-249.

SHARP, W. M. and H. H. CHISMAN (1961): Flowering and fruiting in the white oaks. I. Staminate flowering through pollen dispersal. Ecology 42: 365-372.

Smouse, P. E., R. J. Dyer, R. D. Westrall and V. L. Sork (2001): Two-generation analysis of pollen flow across a landscape. I. Male gamete heterogeneity among females. Evolution 55: 260-271.

Steinkellner, H., S. Fluch, E. Turetschek, C. Lexer, R. StreifF, A. Kremer, K. Burg and J. Glossl (1997): Identification and characterization of $(\mathrm{GA} / \mathrm{CT}) \mathrm{n}$ - microsatellite loci from Quercus petraea. Plant Mol Bio 33: 1093-1096.

Streiff, R., A. Ducousso, C. Lexer, H. Steinkellner, J. Gloessl and A. Kremer (1999): Pollen dispersal inferred from paternity analysis in a mixed oak stand of Quercus roubur L. and Q. petraea (Matt.) Liebl. Mol Ecol 8: 831-841.

TAGAWA, H. (1995): Distribution of lucidophyll oak-laurel forest formation in Asia and other areas. Tropics 5: 1-40.

Whitlock, M. C. and D. E. McCAUley (1999): Indirect mesures of gene flow and migration: $F_{\mathrm{ST}} \neq 1 /(4 \mathrm{Nm}+1)$. Heredity 82 $117-125$.

\title{
Variation in Growth Performance of Acacia nilotica Willd. ex Del. Provenances of Wide Geographical Origin : Six Year Results
}

\author{
By H. S. GinwaL* and A. K. MANDAL
}

Division of Genetics and Tree Propagation, Forest Research Institute, P.O. I.P.E. Kaulagarh Road, Dehradun (Uttaranchal) - 248195 INDIA

(Received $8^{\text {th }}$ November 2004)

\begin{abstract}
Results of a provenance trial of Acacia nilotica Willd. ex Del. laid out in 1993 at Tropical Forest Research Institute Campus, Jabalpur $\left(23^{\circ} \mathrm{N}\right.$ lat., $79^{\circ} \mathrm{E}$ long. and $400 \mathrm{~m}$ altitude) Madhya Pradesh, a semi-arid region of India are reported and discussed. Nineteen provenances from India, Pakistan, Sudan,
\end{abstract}

\footnotetext{
*) Author for correspondence

(e-mail: ginwalhs@icfre.org; ginwalhs@rediffmail.com
}

Senegal and Yemen were evaluated in the field at age three and six years. Local source of A. nilotica (S.F.R.I., Jabalpur) was used as check material for comparison. Significant differences between the provenances $(\mathrm{P}<0.05)$ were observed for height, diameter at breast height $(\mathrm{DBH})$, number of branches and field survival. The provenances from Gujrat (Punjab), Pakistan, ranked first for growth traits namely height, $\mathrm{DBH}$ and survival. The next superior provenance was from Beihan, Yemen, which scored second highest values of height and DBH and had good survival at age six years. Results indicate that 
genetic differences exist between the provenances of A.nilotica. None of the traits assessed (viz. height, $\mathrm{DBH}$, number of branches, inter-nodal length and survival) were found to correlate with any of the geographical coordinates of the provenances (latitude, longitude and altitude). Height, DBH and number of branches showed significant and positive correlation with each other. Fair differences between phenotypic and genotypic coefficient of variability were observed. Heritability values were found fairly good for height, $\mathrm{DBH}$ and number of branches as compared to inter-nodal length. The relative performance of these provenances was fairly consistent throughout the period of observation at three and six year. The two sources viz. Gujrat (Punjab), Pakistan and Beihan, Yemen, are recommended for plantation programme under semi-arid conditions.

Key words: Acacia nilotica, variation, provenance, seed source, genetic improvement, productivity, heritability.

\section{Introduction}

Acacia nilotica Willd. ex Del. is a fast growing multipurpose tree species of India that provides high quality wood and other products (ANON., 1980). It is recognized into nine subspecies or varieties and is a very variable species with a natural distribution covering large tracts of tropical and subtropical Africa and Asia (BRenan, 1983; Ross, 1979). In India, it occurs extensively on a wide strip from north to south of the country under varied ecological conditions, though it is widely planted in afforestation programmes in the plains of arid and semi-arid regions. Farmers with small holding value this leguminous species by virtue of its nitrogen fixing ability and improving the fertility of soil, good coppicing ability, green manure, providing fodder, fuel, timber to some extent and excellent characteristics as an agroforestry tree species (VISHWANATH and KAUSHIK, 1993). It is also a most sought after species for afforestation program in controlling the shifting sand dunes, coastal sands, river beds, saline lands, dry and degraded lands and waste lands where rainfall is scanty and erratic.

In India, A. nilotica though occurs naturally in extensive areas but due to a long history of selective felling and biotic interference has resulted it in small discrete populations that appear degraded. These dwindling natural populations are the basic material for future breeding and are the only source material for bringing improvement in future plantations. Hence a comprehensive exploration and mapping of natural populations, which are disappearing fast needed to be undertaken (GINWAL and GERA, 2000).

The significance of genetic variation studies and provenance testing in forest tree improvement is very well realized (PRYOR, 1963; CALLAHAM, 1964; WRIGHT, 1976). Exploration of naturally

Table 1. - Details of provenances of Acacia nilotica and their geographical locations.

\begin{tabular}{|c|c|c|c|c|c|c|c|c|}
\hline $\begin{array}{l}\text { Proven } \\
\text { ance } \\
\text { No. }\end{array}$ & Species/variety & Provenance & Locality & Country & Latitude & Longitude & $\begin{array}{l}\text { Rainfall } \\
(\mathrm{mm})\end{array}$ & $\begin{array}{l}\text { Altitude } \\
\text { (meter) }\end{array}$ \\
\hline S1 & Acacia nilotica & $\begin{array}{l}\text { Khartoum } \\
\text { Forest }\end{array}$ & $\begin{array}{l}\text { White Nile, } \\
\text { Khartoum }\end{array}$ & Sudan & $15^{\circ} 36^{\prime} \mathrm{N}$ & $32^{0} 33^{\prime} \mathrm{E}$ & 165 & 330 \\
\hline S2 & “ & Ngouye & $\begin{array}{l}\text { Dept. Podar, Reg. } \\
\text { Fleuve }\end{array}$ & Senegal & $16^{\circ} \mathrm{N}$ & $14^{\prime} \mathrm{W}$ & 315 & 10 \\
\hline S3 & $\begin{array}{l}\text { A. nilotica } \\
\text { spp. tomentosa }\end{array}$ & $\begin{array}{l}\text { Forest class, } \\
\text { Richard-Toll }\end{array}$ & $\begin{array}{l}\text { Dep. Dagana, } \mathrm{R} \text {. } \\
\text { Fleuve }\end{array}$ & Senegal & $16^{\circ} 28^{\prime} \mathrm{N}$ & $15^{\circ} 42^{\prime} \mathrm{W}$ & 300 & 4 \\
\hline $\mathrm{S} 4$ & “ & Lambewa Forest & $\begin{array}{l}\text { Near Singa, Blue } \\
\text { Nile }\end{array}$ & Sudan & $13^{\circ} 07^{\prime} \mathrm{N}$ & $33^{\circ} 6^{\prime} \mathrm{E}$ & 538 & 430 \\
\hline S5 & $\begin{array}{l}\text { A.nilotica ssp. } \\
\text { indica var. } \\
\text { jaquemontii }\end{array}$ & Nizamabad & Adilabad, (A.P.) & India & $18^{\circ} 40^{\prime} \mathrm{N}$ & $78^{\circ} \quad 06^{\prime} \mathrm{E}$ & 1086 & 381 \\
\hline S6 & “ & Ajamgarh & U.P. & India & $26^{\circ} 03^{\prime} \mathrm{N}$ & $83^{\circ} 30^{\prime} \mathrm{E}$ & 1047 & 78 \\
\hline S7 & “ & Salem & Tamilnadu & India & $11^{\circ} 39^{\prime} \mathrm{N}$ & $78^{\circ} 10^{\prime} \mathrm{E}$ & 965 & 278 \\
\hline S8 & $"$ & Banaskantha & Gujrat & India & $24^{0} \mathrm{~N}$ & $72^{0} 30^{\prime} \mathrm{E}$ & 823 & 55 \\
\hline S9 & $\begin{array}{l}\text { A.nilotica ssp. } \\
\text { indica, var. } \\
\text { cuppressiformis }\end{array}$ & Pune & Maharashtra & India & $18^{\circ} 32^{\prime} \mathrm{N}$ & $73^{\circ} 51^{\prime} \mathrm{E}$ & 714 & 559 \\
\hline $\mathrm{S} 10$ & " & Maratwara & Maharashtra & India & $20^{\circ} 56^{\prime} \mathrm{N}$ & $77^{0} 47^{\prime} \mathrm{E}$ & 974 & 370 \\
\hline S11 & $\begin{array}{l}\text { A. nilotica } \\
\text { ssp. nilotica }\end{array}$ & $\begin{array}{l}\text { Khartoum } \\
\text { Forest Nile }\end{array}$ & $\begin{array}{l}\text { Along White, } \\
\text { Khartoum }\end{array}$ & Sudan & $15^{0} 36^{\prime} \mathrm{N}$ & $32^{0} 33^{\prime} \mathrm{E}$ & 165 & 330 \\
\hline $\mathrm{S} 12$ & A. nilotica & Patoki & Nr. Lahore, Punjab & Pakistan & $31^{\circ} 05^{\prime} \mathrm{N}$ & $73^{\circ} 30^{\prime} \mathrm{E}$ & 350 & 200 \\
\hline $\mathrm{S} 13$ & “ & D.I. Khan & N.W.F.P & Pakistan & $31^{0} 15^{\prime} \mathrm{N}$ & $70^{\circ} 45^{\prime} \mathrm{E}$ & 300 & 330 \\
\hline S14 & “ & Muzaffargarh & Punjab & Pakistan & $30^{0} 05^{\prime} \mathrm{N}$ & $71^{0} 10^{\prime} \mathrm{E}$ & 200 & 170 \\
\hline S15 & “ & Sukhur & Sind & Pakistan & $28^{0} \mathrm{~N}$ & $68^{\circ} \mathrm{E}$ & 100 & 50 \\
\hline S16 & “ & Gujrat & Punjab & Pakistan & $32^{\circ} 49^{\prime} \mathrm{N}$ & $73^{\circ} 53^{\prime} \mathrm{E}$ & 500 & 220 \\
\hline S17 & “ & Beihan & - & Yemen & $14^{0} 50^{\prime} \mathrm{N}$ & $45^{\circ} 50^{\prime} \mathrm{E}$ & 276 & 9 \\
\hline $\mathrm{S} 18$ & " & Ferozepure & Punjab & India & $30^{\circ} 15^{\prime} \mathrm{N}$ & $74^{\circ} 10^{\prime} \mathrm{E}$ & 537 & 200 \\
\hline S19 & “ & $\begin{array}{l}\text { Mahendergarh, } \\
\text { Bhiwani }\end{array}$ & Hissar, Haryana & India & $28^{\circ} 3^{\prime} \mathrm{N}$ & $76^{\circ} 7^{\prime} \mathrm{E}$ & 714 & 250 \\
\hline $\mathrm{S} 20$ & “ & S.F.R.I. & Jabalpur, M.P. & India & $23^{\circ} 6^{\prime} \mathrm{N}$ & $79^{\circ} 59^{\prime} \mathrm{E}$ & 1358 & 400 \\
\hline
\end{tabular}


existing variability offers scope to tree breeder for making rapid genetic advance at relatively low cost in terms of energy and finance. The form and growth of A. nilotica varies considerably in different provenances (SHIVKUMAR and BANERJEE, 1986; KRISHAN and ToKY, 1995). Considerable seed source and provenance difference in A. nilotica have been reported in seed, seedling characteristics and early growth performance in many recent studies conducted in India (GINwAL et al., 1994, 1995, 1996; MATHUR et al., 1984; SHIVKUMAR and BANERJEe, 1986; BAGCHI et al., 1990; BAGCHI and DoBRIYAL, 1990). However, information on field performance of the provenances is little (ShivkUMAR and BANERJEe, 1986; Krishan and TOKY, 1995), that too on provenances emanating from wide geographical zones.

The apparent high phenotypic variability between the populations (SHIVkUMAR and BANERJEe, 1986; Ginwal et al., 1995, 1996; KRISHAN and TOKY, 1995) in seed and seedling characteristics of A. nilotica warrants for evaluating provenances in field for achieving the economic benefits through selection. The present investigation was undertaken to find out the pattern and magnitude of genetic variation in growth characteristics of 20 A. nilotica provenances of wide geographical origin representing five countries viz. India, Sudan, Senegal, Pakistan and Yemen. The objective was to identify the best provenance based on growth and adaptability, which could be utilized for reforestation work for enhancement in productivity of the plantations and also in genetic improvement programme.

\section{Material and Methods}

The study was conducted in the experimental area of Tropical Forest Research Institute, Jabalpur (situated between $23^{\circ}$ 5' $07^{\prime \prime}$ to $23^{\circ} 6^{\prime} 10^{\prime \prime} \mathrm{N}$ lat. and $79^{\circ} 59^{\prime} 49^{\prime \prime}$ to $79^{\circ} 59^{\prime} 42^{\prime \prime}$ E. long., 400 meter altitude), India. The area enjoys semi-arid type of climate with mean annual rainfall $1350 \mathrm{~mm}$. The soil of the experimental area is well drained, clay loam with shallow depth $(25-50 \mathrm{~cm})$ and contains slight surface stoniness $(3-5 \%)$.
Seeds of 19 different provenances were received through DANIDA Forest Seed Center, Denmark, during 1992 (Table 1). The local population from State Forest Research Institute (S.F.R.I.), Jabalpur was used as check material (local control). Seeds were pretreated with boiled water for 5 minutes prior to sowing. 400 seeds of each of the 19 provenances along with control (check material) were directly sown in polythene bags $(20 \mathrm{x}$ $40 \mathrm{~cm}$ size with one seed per bag) containing potting mixture of sand, soil and farm yard manure in the ratio of 1:1:1 (by volume). The polythene bags were placed in nursery on a polythene sheet in randomized complete block design with 4 replications in an open ground and watered daily. The germination of the seeds was recorded and the seedlings were maintained in the nursery till they attained a plantable height.

Four-month-old seedlings were planted in the field (pit size $60 \times 60 \times 60 \mathrm{~cm}$ ) in August 1993 in a randomized complete block design with 4 replications. Each provenance constituted a square plot with 25 trees $(5 \times 5)$ at the spacing of $3 \times 3 \mathrm{~m}$ between plants. Nine central trees in each plot constituted the measuring unit. The assessment of the trial for various traits viz. plant height $(\mathrm{m})$, diameter at breast height $(\mathrm{cm})$, number of branches, inter-nodal length and survival per cent was made on yearly basis in September every year. In this paper the growth data recorded in September 1996 and 1999 have been reported and described.

The data were subjected to analysis of variance (ANOVA) for confirming the differences between the provenances and further analyzed for Least Significant Difference (LSD), test for checking the homogeneity between the provenances using SPSS (Version 6.1) computer program (SPSS Inc. 233 S. Wacker Drive, $11^{\text {th }}$ floor, Chicago, IL 60606-6307). Coefficient of variation $(\mathrm{CV} \%)$ and linear correlation coefficient among the studied traits and with latitude, longitude and altitude of seed origin of the provenances were calculated as described by SNEDECOR and COCHRAN (1967). Genotypic and phenotypic variances and their coefficient of variation and heritability were calculated using the method of KEMPTHORNE (1957).

Table 2. - Growth performance of various provenances after three and six year of field planting.

\begin{tabular}{|c|c|c|c|c|c|c|c|c|c|}
\hline \multirow{2}{*}{$\begin{array}{l}\text { Provenance } \\
\text { code }\end{array}$} & \multicolumn{4}{|c|}{3 year } & \multicolumn{5}{|c|}{6 year } \\
\hline & \begin{tabular}{|l|} 
Height $(\mathrm{m})$ \\
\end{tabular} & $\begin{array}{l}\text { D.B.H. } \\
(\mathrm{cm})\end{array}$ & $\begin{array}{l}\text { Number of } \\
\text { branches }\end{array}$ & $\begin{array}{l}\text { Survival } \\
(\%)\end{array}$ & Height (m) & D.B.H. $(\mathrm{cm})$ & $\begin{array}{l}\text { Number of } \\
\text { branches }\end{array}$ & $\begin{array}{l}\text { Inter nodal } \\
\text { length }(\mathrm{cm})\end{array}$ & \begin{tabular}{|l|}
$\begin{array}{l}\text { Survival } \\
(\%)\end{array}$ \\
\end{tabular} \\
\hline S1 & $2.2 \mathrm{cdef}$ & 3.9 bcde & 45.7 bcde & 83.3 & $4.1 \mathrm{abc}$ & $11.1 \mathrm{bcd}$ & 55.5 bcde & 6.68 & 77.8 \\
\hline S2 & 2.2 bcdef & 4.0 bcde & $53.5 \mathrm{ab}$ & 69.4 & $4.2 \mathrm{abcd}$ & $11.3 \mathrm{bcd}$ & $63.2 \mathrm{ab}$ & \begin{tabular}{|l|}
6.87 \\
\end{tabular} & 58.3 \\
\hline S3 & \begin{tabular}{|l|}
$2.1 \mathrm{defg}$ \\
\end{tabular} & 4.0 bcde & $40.2 \mathrm{def}$ & 72.2 & 3.9 abcde & $11.0 \mathrm{bcd}$ & 49.7 ef & 6.78 & 61.1 \\
\hline S4 & $1.9 \mathrm{efg}$ & $3.4 \mathrm{de}$ & $40.2 \mathrm{def}$ & 80.6 & 3.8 bcde & $10.9 \mathrm{~cd}$ & $49.7 \mathrm{ef}$ & 6.73 & 72.2 \\
\hline S5 & $2.4 \mathrm{abc}$ & 4.3 bcde & $55.5 \mathrm{a}$ & 76.4 & $4.1 \mathrm{abc}$ & $11.2 \mathrm{bcd}$ & $64.5 \mathrm{a}$ & 6.82 & 65.3 \\
\hline S6 & 2.1 cdefg & $3.6 \mathrm{cde}$ & 47.2 abcde & 85.3 & $4.0 \mathrm{abcde}$ & $10.8 \mathrm{~cd}$ & 57.0 abcde3 & 6.67 & 75.0 \\
\hline S7 & \begin{tabular}{|l|}
$2.1 \mathrm{defg}$ \\
\end{tabular} & $4.5 \mathrm{abc}$ & 39.0 ef & 86.1 & 3.9 bcde & $11.5 \mathrm{bc}$ & $49.5 \mathrm{ef}$ & 6.55 & 77.8 \\
\hline S8 & $1.8 \mathrm{gh}$ & $3.5 \mathrm{cde}$ & $36.7 \mathrm{f}$ & 72.2 & $3.7 \mathrm{def}$ & $10.3 \mathrm{~d}$ & $46.5 \mathrm{f}$ & 6.67 & 50.0 \\
\hline S9 & $1.6 \mathrm{~h}$ & $3.3 \mathrm{e}$ & $39.0 \mathrm{ef}$ & 83.3 & $3.4 \mathrm{f}$ & $10.2 \mathrm{~d}$ & 49.0 ef & 6.56 & 77.8 \\
\hline $\mathrm{S} 10$ & $2.3 \mathrm{bcd}$ & 4.2 bcde & 47.2 abcde & 78.3 & 4.0 abcde & $11.1 \mathrm{bcd}$ & 56.7 abcde & \begin{tabular}{|l|}
6.64 \\
\end{tabular} & 72.2 \\
\hline S11 & $1.9 \mathrm{efg}$ & \begin{tabular}{|l|}
$3.7 \mathrm{cde}$ \\
\end{tabular} & $41.0 \mathrm{cdef}$ & 83.3 & $3.9 \mathrm{bcde}$ & $10.7 \mathrm{~cd}$ & $51.0 \mathrm{cdef}$ & 6.76 & \begin{tabular}{|l|}
87.6 \\
\end{tabular} \\
\hline $\mathrm{S} 12$ & $1.8 \mathrm{fgh}$ & $3.8 \mathrm{cde}$ & $41.7 \mathrm{cdef}$ & 69.4 & $3.8 \mathrm{cdef}$ & $10.9 \mathrm{~cd}$ & $51.5 \mathrm{cdef}$ & 6.70 & 35.3 \\
\hline S13 & $2.1 \mathrm{bcde}$ & $3.7 \mathrm{cde}$ & $49.0 \mathrm{abcd}$ & 61.1 & $4.1 \mathrm{abc}$ & $10.9 \mathrm{~cd}$ & \begin{tabular}{|l|}
$59.0 \mathrm{abc}$ \\
\end{tabular} & 6.83 & 55.6 \\
\hline S14 & 2.2 bcdef & 4.2 bcde & $44.0 \mathrm{cdef}$ & 87.2 & $4.0 \mathrm{abcde}$ & $11.1 \mathrm{bcd}$ & $54.0 \mathrm{cdef}$ & 6.59 & 68.8 \\
\hline S15 & $2.4 \mathrm{abcd}$ & 4.0 bcde & $42.0 \mathrm{cdef}$ & 83.3 & $4.1 \mathrm{abc}$ & $11.1 \mathrm{bcd}$ & $51.2 \mathrm{cdef}$ & 6.56 & 72.2 \\
\hline S16 & $2.7 \mathrm{a}$ & $5.5 \mathrm{a}$ & $53.7 \mathrm{ab}$ & 88.9 & $4.3 \mathrm{a}$ & $12.6 \mathrm{a}$ & $63.2 \mathrm{ab}$ & 6.59 & 88.9 \\
\hline S17 & $2.5 \mathrm{ab}$ & $4.9 \mathrm{ab}$ & $54.2 \mathrm{ab}$ & 83.3 & $4.2 \mathrm{ab}$ & $12.0 \mathrm{ab}$ & $64.0 \mathrm{ab}$ & 6.71 & 66.7 \\
\hline S18 & $1.7 \mathrm{gh}$ & 3.9 bcde & $40.2 \mathrm{def}$ & 77.8 & 3.7 ef & $10.9 \mathrm{~cd}$ & $50.2 \mathrm{def}$ & 6.69 & 69.4 \\
\hline S19 & 2.1 bcdefg & $4.4 \mathrm{bcd}$ & $49.5 \mathrm{abc}$ & 72.2 & $4.0 \mathrm{abcd}$ & $11.5 \mathrm{abc}$ & $58.5 \mathrm{abcd}$ & 6.78 & 52.8 \\
\hline S20 & $1.9 \mathrm{fg}$ & 3.9 bcde & 39.0 ef & 75.0 & $3.8 \mathrm{cdef}$ & $10.9 \mathrm{bcd}$ & $48.5 \mathrm{ef}$ & 6.65 & 61.1 \\
\hline $\mathrm{F}$ test & *** & * & $* * *$ & N.S. & ** & * & $* * *$ & N.S. & * \\
\hline $\mathrm{CV}(\%)$ & 12.41 & 18.03 & 14.50 & & 7.31 & 6.63 & 11.21 & 2.57 & \begin{tabular}{|l|}
19.17 \\
\end{tabular} \\
\hline $\mathrm{CD}(5 \%)$ & 0.354 & 1.036 & \begin{tabular}{|l|}
8.83 \\
\end{tabular} & - & 0.372 & 1.043 & \begin{tabular}{|l|}
8.67 \\
\end{tabular} & - & 27.97 \\
\hline $\mathrm{SE}+$ & \begin{tabular}{|l|}
0.176 \\
\end{tabular} & \begin{tabular}{|l|}
0.517 \\
\end{tabular} & \begin{tabular}{|l|}
4.41 \\
\end{tabular} & - & 0.186 & \begin{tabular}{|l|}
0.521 \\
\end{tabular} & \begin{tabular}{|l|}
4.33 \\
\end{tabular} & - & 13.85 \\
\hline
\end{tabular}

Means followed by the same letter(s) do not differ $(\mathrm{P}<0.05)$ by LSD test.

$* \mathrm{P}<0.05$ level of significance, ${ }^{* * *} \mathrm{P}<0.001$ level of significance, $\mathrm{NS}-$ non significant. $\mathrm{CD}=$ critical difference, $\mathrm{SE}=$ standard error of mean. 


\section{Results}

The provenances under the trial belongs to two African subspecies viz. nilotica and tomentosa and two Indian varieties viz. subsp. indica var. cupressiformis and subsp. indica var. jaquemontii. However, no apparent pattern of differences was observed between the different subspecies included in the trial.

Data on field growth (three and six years) in respect of morphological traits viz. height, diameter at breast height (DBH), number of branches, inter-nodal length and survival percentage pertaining to 20 provenances are presented in Table 2. Variation between the provenances in growth traits at the age of three years was found significant $(\mathrm{P}<0.05)$ except for survival per cent. The provenance S16 attained a maximum height, followed by S17, S5, and S15, which were statistically at par with each other. These provenances performed better than the local (control) seed source S20. Similarly maximum diameter (DBH) was registered in $\mathrm{S} 16$ followed by $\mathrm{S} 17$, and $\mathrm{S} 1$. These were also statistically at par in performance. The S9 provenance resulted in the minimum height and $\mathrm{DBH}$. The S5 provenance was found to be the most-branchy one, however it was at par with S17, S16, S2, S19, S13, S10 and S6. Field survival was recorded maximum in S16, which was closely followed by S14, S7 and S6. The minimum survival was observed in $\mathrm{S} 13$ provenance. The range of variation was considerably good in respect of the traits studied as evident from the values of coefficient of variation. Over all, the performance of S16, S17 and S5 provenances was found better than others.

A clear-cut distinction in the performance of the provenances was observed at age six years (Table 2) wherein the S16 provenance out ranked the rest. Though maximum height growth was shown by S16 at this age, but was statistically at par with other 11 provenances viz. S17, S13, S15, S5, S1, S2, S19, S14, $\mathrm{S} 10, \mathrm{~S} 6$ and S3. The S9 provenance registered the minimum height, but was at par with $\mathrm{S} 18, \mathrm{~S} 8, \mathrm{~S} 20$ and $\mathrm{S} 12$. The local seed source S20 performed very poor and ranked fourth-last in respect of height growth. A similar pattern in $\mathrm{DBH}$ was observed wherein S16 put maximum diameter followed by S17 and S19. However, these three provenances were observed statistically at par in respect of $\mathrm{DBH}$. The lowest $\mathrm{DBH}$ was recorded in S9 provenance. The S5 provenance maintained its superiority even at age six years and produced maximum number of branches. However, it was at par with S17, S16, S2, S13, $\mathrm{S} 19, \mathrm{~S} 6$ and $\mathrm{S} 10$ for this trait. The S8 source showed the lowest number of branches. The inter-nodal length was recorded maximum in S2 and minimum in S7. No significant differences were observed between the provenances for inter-nodal length. The S16 provenance also registered its superiority with a fair margin in respect of survival per cent $(88.9 \%)$. The per cent survival in local seed source S20 was $61.1 \%$. The lowest survival $(35.3 \%)$ was however recorded in S12. The coefficient of variation for height, $\mathrm{DBH}$, number of branches, inter-nodal length and field survival was found to be $7.31,6.63,11.21,2.57$ and 19.17 per cent respectively.

Based on the performance of provenances at age three and six years, the fastest growth was recorded in S16 thus making it most promising in comparison to other sources. The performance of this provenance remained consistent throughout the observation period of three and six years age. The local control S20 did not perform well during the period of observation and stood far behind many provenances with a fair margin particularly in height, DBH and survival.

The correlation coefficient ( $\mathrm{r}$ ) among the various traits across the age is presented in Table 3. Height was found to have higher significant positive relationship $(\mathrm{P}<0.01)$ with $\mathrm{DBH}$ and number of branches at age three and six years. DBH was found to have significant positive relationship $(\mathrm{P}<0.01)$ with number of branches at both observation periods. Height, DBH and number of branches at age three years were found significantly and positively correlated with height, $\mathrm{DBH}$ and number of branches at six age years. Field survival of both the observation periods showed inter-correlation significantly and positively with each other.

Variance components and broad sense heritability for growth traits at age six years are presented in Table 4. There were fair differences between the values of genotypic and phenotypic variance and genotypic and phenotypic co-efficient of variation for all the characters. Estimates of heritability (\%) of growth traits were moderate to high which ranged from 5.46 to $39.42 \%$. High heritability was obtained for number of branches, height and $\mathrm{DBH}$, however the values for the same were low in respect of inter-nodal length.

\section{Discussion}

A. nilotica is a very variable species in habit and morphology which evidenced in nine subspecies, and this is reflected in the manner in which their prime use varies depending on the

Table 3. - Correlation coefficient ( $\mathrm{r}$ ) among the various traits.

\begin{tabular}{|c|c|c|c|c|c|c|c|c|c|}
\hline & \multicolumn{4}{|c|}{3 Year } & \multicolumn{5}{|c|}{6 Year } \\
\hline & Height & DBH & $\begin{array}{l}\text { Number of } \\
\text { branches }\end{array}$ & Survival & Height & DBH & $\begin{array}{c}\text { Number of } \\
\text { branches }\end{array}$ & $\begin{array}{l}\text { Inter-nodal } \\
\text { length }\end{array}$ & Survival \\
\hline \multicolumn{10}{|l|}{3 Year } \\
\hline Height & 1.000 & & & & & & & & \\
\hline$\overline{\mathrm{DBH}}$ & $.759^{\star *}$ & 1.000 & & & & & & & \\
\hline $\begin{array}{l}\text { Number of } \\
\text { branches }\end{array}$ & $.783^{\star \star}$ & $.602^{\star \star}$ & 1.000 & & & & & & \\
\hline Survival & .199 & 320 & -.041 & 1.000 & & & & & \\
\hline \multicolumn{10}{|l|}{6 year } \\
\hline Height & $.955^{\star \star}$ & $.680^{\star \star}$ & $769^{\star \star}$ & .092 & 1.000 & & & & \\
\hline DBH & $.807^{\star \star}$ & $.952^{\star \star}$ & $.664^{\star \star}$ & .269 & $.755^{\star \star}$ & 1.000 & & & \\
\hline $\begin{array}{c}\text { Number of } \\
\text { branches }\end{array}$ & $.778^{\star \star}$ & $.605^{\star \star}$ & $.998^{* *}$ & -.031 & $.765^{\star \star}$ & $.665^{\star *}$ & 1.000 & & \\
\hline $\begin{array}{l}\text { Inter-nodal } \\
\text { length }\end{array}$ & .081 & -.133 & .429 & $-.699^{\star \star}$ & .216 & -.029 & .420 & 1.000 & \\
\hline Survival & .248 & .249 & .046 & $.802^{\star \star}$ & .144 & .228 & .060 & -.420 & 1.000 \\
\hline
\end{tabular}

** Significant at the 0.01 level (2-tailed). 
Table 4. - Estimates of genetic parameters for growth traits at age 6 years.

\begin{tabular}{|l|c|c|c|c|}
\hline Parameters & Height & DBH & $\begin{array}{c}\text { Branch } \\
\text { Number }\end{array}$ & $\begin{array}{c}\text { Inter nodal } \\
\text { length }\end{array}$ \\
\hline General mean & 3.597 & 11.11 & 54.637 & 6.6930 \\
\hline Error variance & 0.0692 & 0.5426 & 37.518 & 0.0297 \\
\hline $\begin{array}{l}\text { Genotypic variance } \\
\text { Phenotypic variance }\end{array}$ & 0.0253 & 0.1402 & 24.413 & 0.0016 \\
\hline $\begin{array}{l}\text { Genotypic coefficient of } \\
\text { variance }\end{array}$ & 0.0945 & 0.6829 & 61.931 & 0.0312 \\
\hline $\begin{array}{l}\text { Phenotypic coefficient } \\
\text { of variance }\end{array}$ & 0.0402 & 3.371 & 9.043 & 0.571 \\
\hline $\begin{array}{l}\text { Heritability (\%) } \\
\text { Hence }\end{array}$ & 26.78 & 20.53 & 39.42 & 5.46 \\
\hline
\end{tabular}

region (RAEBILD et al., 2003). The two African subspecies included in this trial, nilotica and tomentosa differ in their ecological requirements (VON MAYDELL, 1986; Ross, 1979; FAGG and BARNES, 1990). Indian subspecies indica is naturally riverine forming low altitude dry forests but it has come to be widely planted as a farm tree on the plains throughout the subcontinent (RAEBILD et al., 2003). One reason of large variability may be the existence of subspecies in provenances, which may show variability in morphology and growth due to differences in their different ecological requirements. The differences in growth and adaptability are largely of geographic origin and are of genetic nature. It is mainly due to the fact that the provenances originated over a wide range of rainfall, temperature and soil types in Africa and Asia and might have experienced marked differences in selective pressure.

Height and diameter are considered as the most important parameters in the evaluation of species and provenances. Apart from indicating productivity and volume they may also be seen as a measure of the adaptability of trees to the environment, tall provenances/trees usually being better adapted to the site than small provenances/trees (RAEBILD et al., 2003). Result of this trial indicates that the provenances of countries other than India particularly Pakistan and Yemen are better performing under the Jabalpur (M.P.) conditions. The provenances from Gujrat (Punjab), Pakistan had by far the best performance, and the growth of provenances from India was moderately good. The local source could not perform well and lagged behind with a fair margin. No explanatory reason for the poor performance of the local source can be given at this stage however, it appears that many of the provenances originated from areas having lesser precipitation than that at Jabalpur (M.P.) India. They are expected to develop better adaptability characters than those provenances, which emanate from higher rain-fed areas. The reason for better growth performance of majority of Pakistan provenances in India could be attributed to the monsoon rainfall in July, August and September months in both the countries. Many Indian provenances also perform well with respect to the height and diameter of the trees viz. S5 from Nizamabad (A.P.), S6 from Azamgarh (U.P.), S19 from Mahendergarh (Haryana) and S10 from Maratwara (Maharashtra).

Survival of plants indicates the adaptability of the provenance to the environment at the trial site. There was a large variation in the survival, ranging from 35.3 to $88.9 \%$. Among the provenances from India, Sudan, Senegal, Pakistan and Yemen, only the provenance of Gujrat (Punjab), Pakistan had a survival approaching $90 \%$. The provenances from Sudan had comparatively better survival (above $70 \%$ ) than the provenances from Senegal and Pakistan. Indian provenances viz. S6 from Ajamgarh (U.P.), S7 from Salem (Tamilnadu), S9 from Pune (Maharashtra) and S10 from Marathwara (Maharashtra) also performed well in survival per cent. The better survival in
Sudanese provenances has also been reported by RAEBILD et al. (2003). Sudanese provenances are expected to have better adaptation mechanism to dryer and harsh conditions and therefore may have shown better survival under semi-arid test conditions. Comparing the origin of the provenances with the conditions of the site no clear picture emerges. One would be interested to expect that a match between climate at the origin and climate at the test site, but the data do not clearly support this.

The local seed source in the present study ranked very low in comparison to others, which is an indication that there is a good scope of selection of promising genotypes from the study material and introduction of germplasm of superior provenances from Pakistan, Yemen and other African countries for the enhancement of productivity. The extent of variability in the base population is measured by different population parameters including genotypic and phenotypic variations and genotypic and phenotypic co-efficient of variation (SUBRAMANIAN et al., 1995). In the present study there were considerable differences between the values of genotypic and phenotypic coefficient of variation for all the characters. This indicates that these characters are sensitive to environmental changes (SuBRAMANIAN et al., 1995). The genotypic co-efficient of variation is comparatively low than the phenotypic coefficient of variation for all the studied traits. The heritability values for the studied traits were fairly good for height, diameter and number of branches. High heritabilities in conjunction with high genetic coefficient of variation (GCV) have been reported to be advantageous for practicing selection (HANSON et al., 1956; BAGCHI et al., 1990). Further, the significant provenance difference coupled with lower error variance signifies heritability for these traits. Heritability in broad sense may give useful indication about the relative value of selection in material in hand and hence an effective selection may bring improvement in those traits.

In view of high heritability for height, diameter, number of branches and their significant positive inter-relationship at age 6 years, indicate that possible simultaneous improvement could be obtained while selecting for one or the other trait. Such relationships may be used to the advantage of the breeder for the improvement of these traits. Variation for all the studied traits was observed non-clinal type as none of the studied trait was found to bear any significant correlation with any of the geographic coordinates i.e. latitude, longitude and altitude.

It would not be justified to draw a conclusion that the Indian provenances cannot perform better than the provenances of Pakistan and Yemen until and unless more provenances of Indian origin are studied for their performance as A. nilotica has wide distribution range in India. However, the results of this study can be applied in taking decision of development of new breeding populations of selected sources of Pakistan and Yemen. Further the existence of significant differences among twenty provenances of $A$. nilotica, for growth performance at age 6 years in field, provides a firm base for establishment of wide-range provenance test; using more evenly distributed populations from the whole range of the species. The two provenances, which ranked high on the basis of growth and survival viz. Gujrat (Punjab), Pakistan and Beihan, Yemen, can be considered for large scale planting programme at Jabalpur (M.P.) site and nearby area under semi-arid conditions. The performance of these two provenances was consistent across the age. Among the Indian provenances the choice remains between provenance from Nizamabad (A.P.), Azamgarh (U.P.), Mahendergarh (Haryana) and Maratwara (Maharashtra). The work further gives a direction to effect and practice selection and initiate studies for genetic improvement of this species. 


\section{Acknowledgement}

The authors are grateful to the Director, Tropical Forest Research Institute, Jabalpur (M.P.) India, for providing necessary facilities for conducting the experiments and DFSC for supplying the seeds of different provenances.

\section{References}

ANon. (1980): Fire wood crops : Shrubs and tree species for energy production. NAS. Washington, DC, $237 \mathrm{pp}$.

BAGCHI, S. K. and N. D. DobRIYAL (1990): Provenance variation in seed parameters of Acacia nilotica. Indian Forester 116: 958-961.

BAGCHI, S. K., D. N. Joshi and D. S. RAWAT (1990): Variation in seed size of Acacia sp. Silvae Genetica 39: 3-4.

BRENAN, J. P. M. (1983): Manual on taxonomy of Acacia species: present taxonomy of four species of Acacia (A. albida, A. senegal, A. nilotica, A. tortilis). FAO, Rome, Italy. $47 \mathrm{pp}$.

CAllaham, R. Z. (1964): Provenance research: investigation of genetic diversity associated with geography. Unasylva 18 $40-50$.

FAGG, C.W. and R. D. BARnes (1990): African Acacias: Study and acquisition of the genetic resources. Final report, ODA Research Scheme R.4348, Oxford Forestry Institute, UK. 170 pp.

GINWAL, H. S. and M. GerA (2000): Genetic variation in seed germination and growth performance of 12 Acacia nilotica provenances in India. Journal of Tropical Forest Science 12 (2): $286-297$.

GinwaL, H. S., M. Gera and R. L. SRIVASTAVA (1994): Germination studies on various provenances of Acacia nilotica. Range Management and Agroforestry 15 (2): 187-197.

Ginwal, H. S., M. Gera and R. L. Srivastava (1995): Provenance variation in growth and biomass production of Acacia nilotica willd. ex Del. seedlings under nursery conditions. Annals of Forestry 3 (1): 35-44.

Ginwal, H. S., M. Gera and R. L. SRIVAStava (1996): Seed source variability in some seed and seedling characteristics of twenty provenances of Acacia nilotica Willd. ex. Del. Range Management \& Agroforestry 17 (1): 49-59.
Hanson, C. H., H. F. Robinson and R. E. Comstock (1956): Biometrical studies of yield in segregating populations of Korean Lespedeza. Agron. J. 48: 268-272.

KEMPTHORNE, O. (1957): An introduction to genetic statistics. John Willey and Sons Ltd., New York.

KrISHAN, B. and O. P. TOKY (1995): Provenance variation in growth characteristics of Acacia nilotica ssp. indica in arid India. Indian Forester 121(3): 179-186.

MathuR, R. S., K. K. Sharma and M. M. S. RAWAT (1984): Germination behaviour of various provenances of Acacia nilotica ssp. indica. Indian Forester 110: 435-449.

PRYOR, L. D. (1963): Provenance in tree improvement with particular reference to Eucalyptus. World Consultation on Forest Genetics and Tree Improvement. FAO/FORGEN 3/2.

Raebild, A., Diallo, Boukary Ousmane, Graudal, Lars, Dao, MADJELIA and SANOU, Josias (2003): Evaluation of a species and provenance trial of Acacia nilotica and A. tortilis at Gonsé, Burkina Faso. Trial no. 11 in the arid zone series Results and Documentation No. 10. Danida Forest Seed Centre, Humlebaek, Denmark.

Ross, J. H. (1979): A conspectus of the African Acacia species. Memoirs of the Botanical Survey of South Africa, 44, $155 \mathrm{pp}$.

SHIVkuMAR, P. and A. C. BANERJEe (1986): Provenance trial of Acacia nilotica. Journal of Tree Science 5 (1): 53-56.

SNedeCoR, G. W. and W. G. Cochran (1967): Statistical Methods. Oxford and IBH, New Delhi, 593 pp.

Subramanian, K. N., A. K. Mandal and A. Nicodemus (1995): Genetic variability and character association in Eucalyptus grandis. Annals of Forestry 3 (2): 134-137.

VISHWANATH, S. and P. K. KAUSHIK (1993): Acacia nilotica paddy agroforestry system of Chattisgarh India. Asia Pacific Agroforestry Network News. No 5, pp. 8.

Von MaYdell, H.-J. (1986): Trees and Shrubs of the Sahel, Their Characteristics and Uses. TZ-Verlagsgesellschaft, Rossdorf, Germany. $525 \mathrm{pp}$.

WRIGHT, J.W. (1976): Introduction to Forest Genetics. Academic Press, New York 463 pp.

\title{
Correlation and Path Analysis Studies Between Biomass and Other Characters in Bombax ceiba $\mathrm{L}$.
}

\author{
By O. P. Chaturvedi* and N. PANDEY \\ Department of Forestry, Rajendra Agricultural University Pusa (Samastipur) - 848 125, Bihar, India
}

(Received $2^{\text {nd }}$ February 2005)

\begin{abstract}
The genotypic and phenotypic correlation and path analysis of plant biomass, plant height, stem diameter and other biomass component traits were analyzed in thirty provenances of Bombax ceiba. In general, the magnitude of genotypic correlations was higher than phenotypic correlations. Stem diameter and plant biomass showed highly significant genotypic correlations with all the traits except the number of secondary
\end{abstract}

\footnotetext{
*) Present address: National Research Centre for Agroforestry, Jhansi284003, Uttar Pradesh, India.
}

branches and plant biomass with leaf biomass. Plant height had the highest positive direct effect on plant biomass followed by the number of primary branches/plant and the number of leaves/plant. On the basis of this study, a higher plant biomass would be achieved through direct selection based on plant height, the number of primary branches and the number of leaves/plant. Therefore, the study is important in selection of traits of economic importance based on other characters, whose direct effect is not visible.

Key words: Bombax ceiba L., provenance, plant biomass, biomass characters, genotypic and phenotypic correlation, path coefficient. 